\title{
Effect of Cerium Loading on Structure and Morphology of Modified Ce-USY Zeolites
}

\author{
Fillipe A. C. Garcia, ${ }^{a}$ Daniel R. Araújo, ${ }^{a}$ Júnia C. M. Silva, ${ }^{a}$ Julio L. de Macedo, ${ }^{a}$ \\ Grace F. Ghesti, ${ }^{b}$ Sílvia C. L. Dias, ${ }^{* a}$ José A. Dias ${ }^{a}$ and Geraldo N. R. Filho ${ }^{c}$ \\ ${ }^{a}$ Laboratório de Catálise, Instituto de Química and ${ }^{b}$ Engenharia de Energia, Faculdade UnB-Gama, \\ Universidade de Brasília, 70910-900 Brasília-DF, Brazil \\ ${ }^{c}$ Centro de Ciências Exatas e Naturais, Universidade Federal do Pará, Rua Augusto Correa No. 1, \\ 66075-010 Belém-PA, Brazil
}

\begin{abstract}
Este trabalho descreve detalhadamente o efeito da quantidade de cério na estrutura e morfologia da zeólita $\mathrm{NH}_{4}$ USY. Ce-USY $\left(2-25 \% \mathrm{~m} / \mathrm{m}\right.$ de $\left.\mathrm{CeO}_{2}\right)$ foi obtido por impregnação úmida de $\mathrm{CeCl}_{3}$ seguida de calcinação a $550{ }^{\circ} \mathrm{C}$ por $8 \mathrm{~h}$. Em quantidades baixas (2-10\%), foi observado que as espécies de cério encontram-se nas posições de troca iônica na rede, enquanto em maiores teores (15-25\%) pequenos agregados formaram-se na superfície da HUSY. Difratometria de raios X (XRD) mostrou apenas reflexões relacionadas à HUSY, confirmando a alta dispersão das espécies de cério, porém as análises por espectroscopia Raman com transformada de Fourier (FT-Raman) detectaram $\mathrm{CeO}_{\mathrm{x}}$ para os materiais acima de $10 \%$. A reação do $\mathrm{CeCl}_{3} \operatorname{com~} \mathrm{NH}_{4} \mathrm{USY}$ produziu $\mathrm{NH}_{4} \mathrm{Cl}$, o qual se decompõe em $\mathrm{HCl}$, ocasionando a desaluminização da rede. Os materiais apresentaram um aumento da razão Lewis/Brønsted com o aumento da quantidade de cério, devido a interação do excesso de cério com os grupos OH da USY e consequente formação de espécies $\mathrm{CeO}_{\mathrm{x}}$.
\end{abstract}

This work describes comprehensibly the effect of cerium loading on the structure and morphology of $\mathrm{NH}_{4} \mathrm{USY}$ zeolite. The Ce-USY (2-25 wt. \% of $\mathrm{CeO}_{2}$ ) was obtained by wet impregnation of $\mathrm{CeCl}_{3}$ followed by calcination at $550{ }^{\circ} \mathrm{C}$ for $8 \mathrm{~h}$. At low loadings (2-10\%), cerium species are mainly located at ion exchange positions in the framework, whereas at higher loadings (15-25\%), small aggregates were formed on the HUSY surface. X-ray diffractograms (XRD) exhibited only the reflections related to HUSY, demonstrating the high dispersion of cerium species, but Fourier transform Raman spectroscopy (FT-Raman) detected $\mathrm{CeO}_{\mathrm{x}}$ for the materials above $10 \%$. Reaction of $\mathrm{CeCl}_{3}$ with $\mathrm{NH}_{4} \mathrm{USY}$ produced $\mathrm{NH}_{4} \mathrm{Cl}$, which decomposed to form $\mathrm{HCl}$, leading to framework dealumination. The materials showed an increased Lewis/Brønsted ratio with increasing cerium loadings due to the interaction between the excess cerium and the $\mathrm{OH}$ groups of USY, and the consequent formation of $\mathrm{CeO}_{\mathrm{x}}$ species.

Keywords: cerium USY zeolite, cerium oxide, ultra stable Y zeolite, solid-state ion exchange, ${ }^{27} \mathrm{Al}$ and ${ }^{29} \mathrm{Si}$ MAS NMR spectroscopy

\section{Introduction}

Faujasite-type zeolites ( $\mathrm{X}$ and $\mathrm{Y}$ ) are largely applied in fluid catalytic cracking (FCC) of crude oil distillates and in hydrodesulfurization of fossil diesel oil and gasoline. ${ }^{1}$ Y zeolites, either in their sodium or ammonium form, can be exchanged for rare earth ions to achieve the following main goals: (i) to prevent aluminum loss from the zeolite structure, which results in enhanced structural resistance

*e-mail: scdias@unb.br, jdias@unb.br to the severe hydrothermal conditions of the regeneration step of FCC, ${ }^{2}$ and (ii) to increase the activity, because the introduction of rare earth species modifies the number of acidic protons through either hydrolysis or enhancement of ionic fields inside the zeolite structure. ${ }^{3}$ Because rare earth cations modify the acidic properties of zeolites, their insertion has an effect on both thermal and mechanical stability, which are important for zeolite application to industrial processes such as pyrolysis, ${ }^{4}$ oxidation, ${ }^{5,6}$ cracking, ${ }^{2}$ hydrogenation, ${ }^{7}$ alkylation ${ }^{8,9}$ and the Fries rearrangement. ${ }^{10}$ 
The use of ceria-based catalysts has been well established for a variety of environmental applications, such as oxidation of diesel soot, ${ }^{10}$ hydrodesulfurization of fossil diesel oil, ${ }^{1}$ low temperature naphthalene and $\mathrm{CO}$ oxidation, ${ }^{11-13} \mathrm{H}_{2} \mathrm{~S}$ adsorption, ${ }^{14}$ water gas shift process ${ }^{15}$ and construction of hydrogen fuel cells. ${ }^{16}$ These applications, especially the oxidation processes, are related to oxygen storage capacity (OSC), which reflects the ability of ceria to release oxygen upon reduction of $\mathrm{Ce}^{\mathrm{IV}}$ and to adsorb oxygen upon the oxidation of $\mathrm{Ce}^{\mathrm{III}}$, completing a redox cycle and allowing the in situ regeneration of the catalyst by gas flow. ${ }^{17}$

The incorporation of cerium species into zeolites has resulted in materials that combine the high activity of ceria with the high surface area and selectivity of zeolites. Reddy et al. ${ }^{18}$ demonstrated the application of cerium(III)modified zeolites (e.g., HZSM-5, MOR and HY) to the photogeneration of hydrogen from water. Velu et al. ${ }^{19}$ reported that the addition of $\mathrm{Ce}^{\mathrm{IV}}$ species to $\mathrm{Y}$ zeolites increased sulfur adsorption capacity and selectivity in comparison with aromatics in jet fuel. These results have indicated that removal of thiophene is greatly influenced by cerium oxidation number and content, the amount of adsorbed water and the structure of the zeolite framework.

Although several studies on cerium-modified zeolites exist, the relationship between cerium loading and zeolite structure is uncertain and has not been systematically approached with respect to the changes that zeolites undergo upon the addition of different amounts of cerium. Therefore, the goal of this work was to synthesize and characterize Ce-USY catalysts within a wide loading range (2-25 wt.\% of $\mathrm{CeO}_{2}$ ) to study the effect of cerium oxide content on both the structure and morphology of USY.

\section{Experimental}

\section{Synthesis of Ce-USY zeolites}

Ce-USY catalysts of 2, 5, 10, 15 and 25 wt.\% were prepared by aqueous impregnation. Cerium chloride heptahydrate $\left(\mathrm{CeCl}_{3} \cdot 7 \mathrm{H}_{2} \mathrm{O}\right.$, Vetec, $\left.99.9 \%\right)$ was used as $\mathrm{Ce}^{\mathrm{III}}$ source and a USY zeolite in the ammoniacal form (Zeolyst, $\mathrm{CBV} 500, \mathrm{SiO}_{2} / \mathrm{Al}_{2} \mathrm{O}_{3}=5.2, \mathrm{Na}_{2} \mathrm{O}=0.2 \%$ ) was used as support. The metal and the support were added to a $100 \mathrm{~mL}$ round-bottom flask with an adequate amount of water to obtain a 1:10 (catalyst:water) mass ratio. Each slurry sample was stirred at $80^{\circ} \mathrm{C}$ until all water evaporated. Finally, the solid was calcined at $550{ }^{\circ} \mathrm{C}$ for $8 \mathrm{~h}$ in a EDG muffle furnace (model 3P-S) with a heating rate of $10^{\circ} \mathrm{C} \mathrm{min}^{-1}$ to obtain the total decomposition of the cerium precursor and the protonic form of the zeolite. After calcination, the catalysts were characterized by a number of techniques, employing the experimental conditions described as follows.

\section{Characterization of Ce-USY zeolites}

Thermogravimetric/derivative thermogravimetric/ differential thermal analyses (TGA/DTG/DTA) data were obtained in a simultaneous TGA/DTA/DSC equipment (model SDT 2960, TA Instruments) with a heating rate of $10{ }^{\circ} \mathrm{C} \mathrm{min}{ }^{-1}$ from room temperature $\left(c a .25^{\circ} \mathrm{C}\right)$ up to $800^{\circ} \mathrm{C}$ under a synthetic air (99.999\%) flow of $50 \mathrm{~mL} \mathrm{~min}^{-1}$. Platinum pans loaded with about $15 \mathrm{mg}$ of sample were used in all runs with $\alpha-\mathrm{Al}_{2} \mathrm{O}_{3}$ as reference.

Nitrogen adsorption/desorption isotherms were obtained at $-196.15{ }^{\circ} \mathrm{C}$ using a gas adsorption analyzer (model Nova 1200, Quantachrome). Surface area and pore volume data were obtained through BET and BJH adsorption and desorption isotherms, respectively. Before analysis, each sample was degassed for $1 \mathrm{~h}$ under vacuum conditions $\left(10^{-5} \mathrm{~mm}\right.$ of $\left.\mathrm{Hg}\right)$ at $300{ }^{\circ} \mathrm{C}$.

Gas phase pyridine (py) adsorption was conducted simultaneously for all samples. Platinum crucibles loaded with the samples $(20 \mathrm{mg})$ were placed in a shallow porcelain plate and inserted into a glass reactor adapted to a tubular furnace (model F21135, Thermolyne). The catalysts were dehydrated in dried $\mathrm{N}_{2}\left(100 \mathrm{~mL} \mathrm{~min}^{-1}\right)$ at $300{ }^{\circ} \mathrm{C}$ for $1 \mathrm{~h}$ and cooled to $100^{\circ} \mathrm{C}$, and then gaseous pyridine diluted in $\mathrm{N}_{2}$ was allowed to pass through the samples for $1 \mathrm{~h}$. The temperature was held at $150^{\circ} \mathrm{C}$ under $\mathrm{N}_{2}$ for $2 \mathrm{~h}$ to remove physically adsorbed pyridine. Subsequently, the samples were analyzed by Fourier transform infrared spectroscopy (FTIR).

X-ray fluorescence (XRF) spectra were obtained with a Shimadzu EDX 720 spectrophotometer with a rhodium $\mathrm{X}$-ray source tube. The XRF spectra were collected under vacuum conditions $(<45 \mathrm{~Pa})$ using two channels, with the X-ray source set at 50 and $15 \mathrm{kV}$ for Ti-U and Na-Sc, respectively. The cerium elemental composition of the prepared samples was determined through an analytical curve built with $\mathrm{CeO}_{2}$ pellets diluted with $\mathrm{H}_{3} \mathrm{BO}_{3}$. The silicon and aluminum content were determined by comparison with fundamental standards (Quali-Quant method).

$\mathrm{X}$-ray powder diffraction (XRD) patterns were recorded on a Bruker D8 FOCUS diffractometer operating at $40 \mathrm{kV}$ and $30 \mathrm{~mA}$ with $\mathrm{Cu}-\mathrm{K}_{\alpha}$ radiation $(\lambda=1.5418 \AA)$ and a graphite monochromator. The Bragg angle (20) range was scanned from 2 to $40^{\circ}$ at 2 degrees $\mathrm{min}^{-1}$. Before the experiment, each sample was mixed with 15 wt.\% of elemental $\mathrm{Si}$ as an internal standard. This standard allows the normalization of the position and intensity of 
the diffractogram, so that the Bragg angle and intensity values can be used to calculate the crystallinity (ASTM D 3906-80) and the unit cell parameter $\mathrm{a}_{0}$ (ASTM D3942-80), according to the literature. ${ }^{20}$

Infrared (FTIR) spectra were recorded on a Nicolet 6700 spectrophotometer (Thermo Scientific) with 128 scans and a spectral resolution of $4 \mathrm{~cm}^{-1}$. Each sample was pressed into dried $\mathrm{KBr}$ (1 wt.\%, Merck) pellets. Framework Si/Al ratios were calculated by equation $1:^{21}$

$\mathrm{X}=3.857-0.00621 w_{\mathrm{DR}}\left(\mathrm{cm}^{-1}\right)$

where $0.1<\mathrm{x}<0.3, w_{\mathrm{DR}}$ is the zeolite specific double ring vibration mode between 570 and $600 \mathrm{~cm}^{-1}$ and $\mathrm{x}=[1+(\mathrm{Si} / \mathrm{Al})]^{-1}$.

Fourier transform Raman (FT-Raman) spectra were obtained at room temperature $\left(\mathrm{ca} .25^{\circ} \mathrm{C}\right)$ with 256 scans and a resolution of $4 \mathrm{~cm}^{-1}$ on a spectrophotometer Bruker (FRA 106/S module attached to an Equinox 55). The wavelength and laser (Nd-YAG) power were $1064 \mathrm{~nm}$ and $100 \mathrm{~mW}$, respectively. A liquid $\mathrm{N}_{2}$-cooled Ge detector collected the Raman signal.

Solid state nuclear magnetic resonance (MAS NMR) experiments were performed with a Varian Mercury Plus spectrometer $(7.05 \mathrm{~T}$ ) equipped with a $7 \mathrm{~mm}$ probe (zirconia rotors with torlon caps). ${ }^{29} \mathrm{Si}$ spectra $(59.609 \mathrm{MHz})$ were recorded with magic angle spinning (MAS) at a speed of $3 \mathrm{kHz}$, a single pulse duration of $5.5 \mu \mathrm{s}(\pi / 2)$, a recycle delay of $20 \mathrm{~s}$ and 500 scans. ${ }^{27} \mathrm{Al}$ spectra $(78.188 \mathrm{MHz})$ were recorded with MAS at a speed of $6 \mathrm{kHz}$, a single pulse duration of $1.0 \mu \mathrm{s}(\pi / 18)$, a recycle delay of $0.4 \mathrm{~s}$ and 2000 scans. The ${ }^{29} \mathrm{Si}$ and ${ }^{27} \mathrm{Al}$ spectra were referenced to the external standards tetramethylsilane and $\left[\mathrm{Al}\left(\mathrm{H}_{2} \mathrm{O}\right)_{6}\right]^{3+}$, respectively $(\delta=0 \mathrm{ppm})$. MAS NMR spectra were deconvoluted using a Gaussian mathematical fit.

Scanning electron (SEM) micrographs were obtained with a Zeiss microscope (LEO 1430) operating at $10 \mathrm{kV}$ and $90 \mathrm{~mA}$ of beam current. The samples were metalized and supported on carbon tape. All micrographs were obtained under vacuum.

\section{Results and Discussion}

\section{Elemental analysis (XRF)}

Elemental analysis of the cerium catalysts and of the pure USY zeolite were performed using X-ray fluorescence (XRF) and energy-dispersive X-ray spectroscopy (EDS) measurements to evaluate the actual amount of cerium (reported as $\mathrm{CeO}_{2}$ ) on each catalyst, the elemental composition of the zeolite and the presence of possible contaminants (e.g., $\mathrm{NaCl})$. The results for the USY zeolite identified the presence of $\mathrm{Si}$ and $\mathrm{Al}$, and, together with the TGA/DTG data (described in the next section), allowed the determination of both water and ammonium contents to obtain the following chemical formula of the zeolite: $\left(\mathrm{NH}_{4}^{+}\right)_{39.7}\left(\mathrm{H}_{2} \mathrm{O}\right)_{169.5}\left[\mathrm{Al}_{39.7} \mathrm{Si}_{152.3} \mathrm{O}_{384}\right]$-USY.

In addition, the results for the supported catalysts indicated that the cerium oxide loadings were in close agreement with the nominal values, and the preparation error did not exceed $\pm 10 \%$ of each value (Table 1 ). Thus, the nominal values will be used henceforth for simplicity. The differences between the nominal and the measured values are probably due to the water content in the cerium chloride precursor. In addition, no chloride was observed in the materials after calcination, which revealed that the precursor was completely decomposed as also attested by TGA (see next section).

\section{Thermal evolution and textural characterization}

Before calcination, DTG curves of the Ce-USY materials presented two mass losses at approximately 110 and $350{ }^{\circ} \mathrm{C}$ (Figure 1). They are related to desorption of water molecules that were physically/chemically adsorbed onto the zeolite surface, followed by evolution of $\mathrm{NH}_{3}$ and $\mathrm{HCl}$. These gases were produced from the decomposition of the $\mathrm{NH}_{4}{ }^{+}$counter ion combined with $\mathrm{Cl}^{-}$from the $\mathrm{CeCl}_{3}$ precursor. In addition, the temperature of the $\mathrm{NH}_{4}^{+}$ decomposition shifted from $400{ }^{\circ} \mathrm{C}$ for the pure zeolite (Figure 1a) to $c a .370{ }^{\circ} \mathrm{C}$ for the exchanged materials.

Table 1. Elemental analysis and textural characterization results of HUSY and Ce-USY catalysts containing $2-25 \mathrm{wt} . \% \mathrm{CeO}_{2}$ calcined at $550{ }^{\circ} \mathrm{C}$ for $8 \mathrm{~h}$

\begin{tabular}{lcccc}
\hline Sample $^{\mathrm{a}}$ & $\mathrm{CeO}_{2} / \mathrm{wt} . \%$ & $\mathrm{~S}_{\mathrm{BET}} /\left(\mathrm{m}^{2} \mathrm{~g}^{-1}\right)$ & $\mathrm{S}_{\text {Micro }} /\left(\mathrm{m}^{2} \mathrm{~g}^{-1}\right)$ & Pore volume $/\left(\mathrm{cm}^{3} \mathrm{~g}^{-1}\right)$ \\
\hline $0^{\mathrm{b}}$ & - & 780 & 731 & 0.03 \\
2 & 2.1 & 574 & 552 & 0.02 \\
5 & 5.4 & 589 & 563 & 0.02 \\
10 & 11.5 & 577 & 538 & 0.03 \\
15 & 14.5 & 495 & 470 & 0.02 \\
25 & 23.9 & 406 & 389 & 0.02 \\
\hline
\end{tabular}

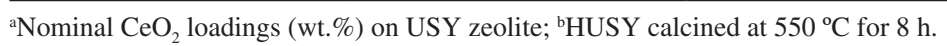




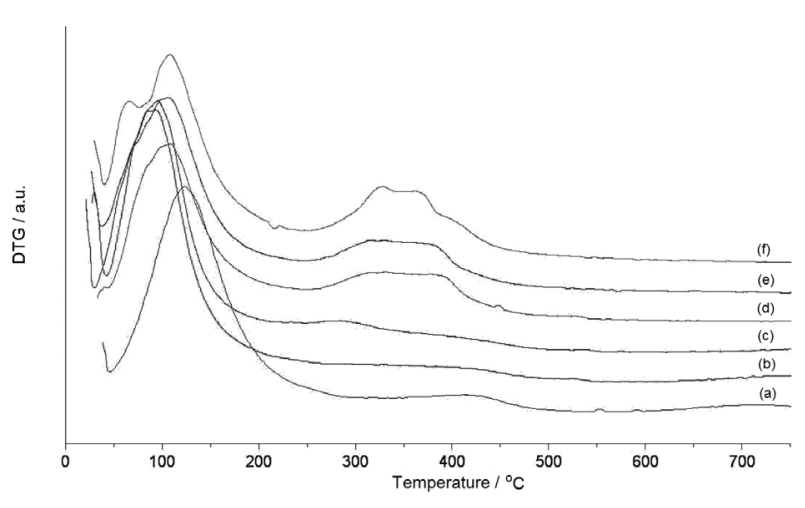

Figure 1. DTG curves, all before calcination, of HUSY (a) and Ce-USY catalysts containing 2 (b), 5 (c), 10 (d), 15 (e) and 25 wt. \% of $\mathrm{CeO}_{2}$ (f).

Actually, the substitution of $\mathrm{NH}_{4}{ }^{+}$ions for $\mathrm{Ce}^{3+}$ may have resulted in formation of $\mathrm{NH}_{4} \mathrm{Cl}$ due to the presence of $\mathrm{Cl}^{-}$ ions, which remained in the solid after impregnation. Pure $\mathrm{NH}_{4} \mathrm{Cl}$ salt usually decomposes by sublimation at about $350^{\circ} \mathrm{C}$; however, this temperature may change due to the confinement of $\mathrm{NH}_{4} \mathrm{Cl}$ inside the pores of the zeolite. ${ }^{20} \mathrm{In}$ contrast, TGA curves obtained after calcination at $550{ }^{\circ} \mathrm{C}$ for $8 \mathrm{~h}$ exhibited only the first mass loss (Figure S1), which is evidence of complete decomposition of the metal precursor, the ammonium counter ion and/or ammonium chloride during calcination. Furthermore, the TGA curve of the $\mathrm{NH}_{4}$ USY zeolite presented a $20 \%$ mass loss, which is related to water desorption and was used to determine the $169.5 \mathrm{H}_{2} \mathrm{O}$ molecules in the chemical formula presented earlier.

Adsorption and desorption of nitrogen in HUSY and Ce-USY zeolites (Figure S2) exhibited reversible type II isotherms (IUPAC classification) that posed an initial increase in the $\mathrm{P} / \mathrm{P}_{0}$ values up to $0.2-0.3$, characteristic of nitrogen adsorption on the zeolite micropores, followed by an exponential increase related to adsorption on multiple superposed layers. ${ }^{22-25}$ Similar nitrogen adsorption isotherms were reported by Yao et al. ${ }^{26}$ and Schneider et al. ${ }^{27}$ for sodalite and $\mathrm{NaY}$ zeolites, respectively.

The zeolite desorption isotherms were analyzed using BET and BJH methods to obtain specific surface areas and pore volumes, respectively (Table 1). The Ce-USY zeolites may be gathered in two different sample sets including one with low Ce loading (2-10 wt.\%) and another with high cerium loadings (15 and 25 wt.\%). The samples with low loadings presented specific surface areas of around $580 \mathrm{~m}^{2} \mathrm{~g}^{-1}$, while those with higher oxide contents exhibited surface areas of around 495 and $406 \mathrm{~m}^{2} \mathrm{~g}^{-1}$ for 15 and $25 \mathrm{wt} \%$, respectively. This decrease in surface area was because cerium species can be deposited on the inner pores and/or on the external surface of the support. Cerium species that are not at ion exchange positions interact with surface sites (e.g., silanol groups) to facilitate particle aggregation with further grain agglomeration, which could lead to formation of $\mathrm{CeO}_{x}$ with lower surface areas. The pore volumes did not change considerably among the samples, suggesting a good dispersion of cerium particles on the surface of the support. Finally, t-plot analysis of the adsorption isotherms (Table 1) revealed that the microporosity of the materials decreased as the content of cerium increased, indicating that the cerium species were preferentially located inside the cavities.

\section{$X$-ray diffraction analysis}

The diffractograms of the Ce-USY catalysts exhibited only the reflections given by the USY zeolite and elemental silicon $\left(2 \theta=28.45^{\circ}\right)$ added as internal standard. No peaks related to the fluorite structure of $\mathrm{CeO}_{2}(2 \theta=28.6,33.3$ and $47.5^{\circ}$ ) were found. ${ }^{28}$ These results indicated that $\mathrm{Ce}^{\mathrm{IV}}$ species were well dispersed on the support surface ${ }^{29,30}$ even at loadings as high as 25 wt.\% (Figure 2), which was in agreement with the nitrogen adsorption-desorption data. In addition, a decrease in the relative intensity of the peaks related to the support with increased cerium loading was observed. This finding was attributed to the loss in zeolite crystallinity and to the higher cerium absorption coefficient of X-ray radiation. ${ }^{2,31}$

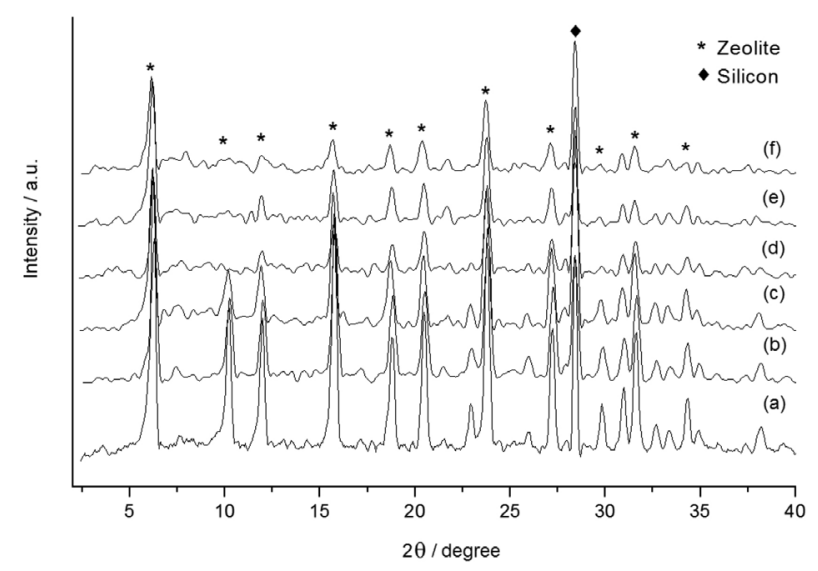

Figure 2. Diffractograms of HUSY (a) and Ce-USY catalysts calcined at $550^{\circ} \mathrm{C}$ for $8 \mathrm{~h}$ containing 2 (b), 5 (c), 10 (d), 15 (e) and $25 \mathrm{wt} \%$ of $\mathrm{CeO}_{2}$ (f).

The ASTM D 3906-80 method allowed the quantitative evaluation of the crystallinity parameter using peak intensities at $2 \theta=10.2,11.9,15.7,18.8,20.5,23.8,27.2$, $30.9,31.6$ and $34.3^{\circ}$, which are related to the reflections on the [220], [311], [331], [511] and [333], [440], [533], [642], [660] and [822], [555] and [751] and [664] planes, respectively. It is important to note that the reflections at the [220] and [311] planes were not originally included in the ASTM method, but were included here to obtain 
a more accurate crystallinity value..$^{20}$ This parameter for Ce-USY catalysts presented a reduction with increasing cerium loadings.

The unit cell parameters $\left(a_{0}\right)$ were calculated using ASTM method D3942-80 after normalization of the diffractograms using an elemental Si standard. The unit cell contracts with an increase of dealuminization and with a decreased amount of $\mathrm{TO}_{4}$ tetrahedra. ${ }^{32,33}$

The $\mathrm{a}_{0}$ values of Ce-USY zeolites depend on structural factors that include the dealuminization process, the ion exchange extent and the presence and location of extraframework aluminum and cerium species. The range of $\mathrm{a}_{0}$ values (24.48-24.60 ̊) obtained for Ce-USY samples (Table 2) was associated with the balance between the dealumination process and the migration of cerium species upon calcination to positions inside the sodalite cage. ${ }^{34,35}$ According to Nery et al. ${ }^{33}$ cerium exchange species are located inside supercages and migrate to sodalite cage sites during calcination, which increases the value of $\mathrm{a}_{0}$. However, the calcination process of zeolites is usually accompanied by framework dealumination that decreases $\mathrm{a}_{0}$, as well as the presence of hydrated rare-earth species and the decomposition of $\mathrm{NH}_{4} \mathrm{Cl}$, which produces protons that catalyze aluminum hydrolysis. ${ }^{34,35}$ The occurrence of these two processes simultaneously explains the gradual loss of crystallinity of the samples with cerium loading, although full interpretation of the unit cell parameters from $\mathrm{XRD}$ is very difficult.

Table 2. XRD crystallinity and $\mathrm{Si} / \mathrm{Al}$ ratio results for Ce-USY zeolites containing 2-25 wt. $\%$ of $\mathrm{CeO}_{2}$ calcinated at $550{ }^{\circ} \mathrm{C}$ for $8 \mathrm{~h}$

\begin{tabular}{lccc}
\hline Sample $^{\mathrm{a}}$ & Crystallinity / \% & $(\mathrm{Si} / \mathrm{Al})_{\mathrm{FTIR}}$ & $\mathrm{a}_{0} / \AA$ \\
\hline $0^{\mathrm{b}}$ & 100 & 4.5 & 24.52 \\
2 & 73.1 & 4.9 & 24.48 \\
5 & 59.7 & 5.4 & 24.57 \\
10 & 27.7 & 7.0 & 24.53 \\
15 & 28.0 & 7.0 & 24.55 \\
25 & 19.9 & 7.9 & 24.60 \\
\hline
\end{tabular}

${ }^{\mathrm{a} N o m i n a l ~} \mathrm{CeO}_{2}$ loading (wt.\%) on USY support; ${ }^{\mathrm{b} H U S Y}$ calcined at $550{ }^{\circ} \mathrm{C}$ for $8 \mathrm{~h}$.

\section{Fourier transform infrared and Raman spectroscopies}

The FTIR spectra of Ce-USY zeolites before calcination presented bands at 1630, 1400, 1180, 1050, 818, 590, 510 and $450 \mathrm{~cm}^{-1}$ (Figure S3). The bands at 1630 and $1400 \mathrm{~cm}^{-1}$ are related to the bending vibrations of $\mathrm{O}-\mathrm{H}$ and $\mathrm{N}-\mathrm{H}$ groups from adsorbed water and $\mathrm{NH}_{4}{ }^{+}$counter ions, respectively. In addition, the bands at 1180 and $818 \mathrm{~cm}^{-1}$ are associated with external linkages among $\mathrm{TO}_{4}$ tetrahedra
( $\mathrm{T}=\mathrm{Si}, \mathrm{Al})$, which are surface-sensitive, while those at 1050 and $450 \mathrm{~cm}^{-1}$ are related to internal linkages of $\mathrm{TO}_{4}$ tetrahedra, which are related to the bulk of USY zeolite. ${ }^{36}$ Because the band at $590 \mathrm{~cm}^{-1}$, which is associated with the zeolite specific double ring vibration mode, is very sensitive to changes in zeolite structure, it was used to calculate the framework Si/Al ratio for all samples..$^{20,37}$ The results obtained (Table 2) showed that, before calcination, the framework $\mathrm{Si} / \mathrm{Al}$ ratio of the samples remained the same as in the parent material (around 4.0).

After calcination, the samples presented lower intensity in all structural bands of the USY zeolite and the band at $1400 \mathrm{~cm}^{-1}$ disappeared (Figure 3). These results corroborate the loss of crystallinity obtained from XRD. In addition, the decomposition of $\mathrm{NH}_{4} \mathrm{Cl}$ led to the formation of $\mathrm{HCl}$ that catalyzed aluminum hydrolysis, increasing the framework dealumination process and the framework $\mathrm{Si} / \mathrm{Al}$ ratio with cerium loading, which reached a value of 7.9 (Table 2).

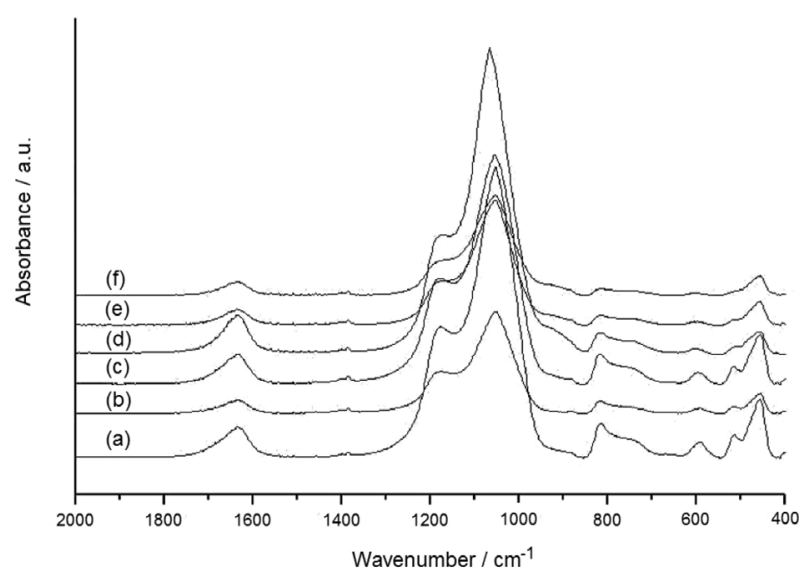

Figure 3. FTIR spectra of HUSY (a) and Ce-USY catalysts calcined at $550{ }^{\circ} \mathrm{C}$ for $8 \mathrm{~h}$ containing 2 (b), 5 (c), 10 (d), 15 (e) and $25 \%$ wt. $\%$ of $\mathrm{CeO}_{2}$ (f).

The FT-Raman spectra of the Ce-USY zeolites are presented in Figure 4. The materials with low loadings (0-10 wt.\%) showed only one band at $500 \mathrm{~cm}^{-1}$ related to the USY zeolite..$^{38}$ Nonetheless, the materials with 15 and $25 \mathrm{wt} . \%$ cerium exhibited an intense Raman shift at $465 \mathrm{~cm}^{-1}$. This band is associated with the symmetric breathing mode of oxygen at neighboring positions of the $\mathrm{Ce}^{\mathrm{IV}}$ ion and is characteristic of a fluorite structure $(\mathrm{Fm} 3 \mathrm{~m}$ space group). ${ }^{39-41}$ The absence of this band for materials with loadings lower than $10 \mathrm{wt} . \%$ and its appearance in materials with $15 \mathrm{wt} . \%$ is related to the higher degree of the $\mathrm{NH}_{4}^{+}-\mathrm{Ce}^{3+}$ ion exchange process. The expected limit of exchange was $13 \mathrm{wt} \%$, so that the excess cerium in non-exchangeable sites have formed small $\mathrm{CeO}_{x}$ species responsible for the observed Raman shift. This result is consistent with nitrogen adsorption and XRD data, since 


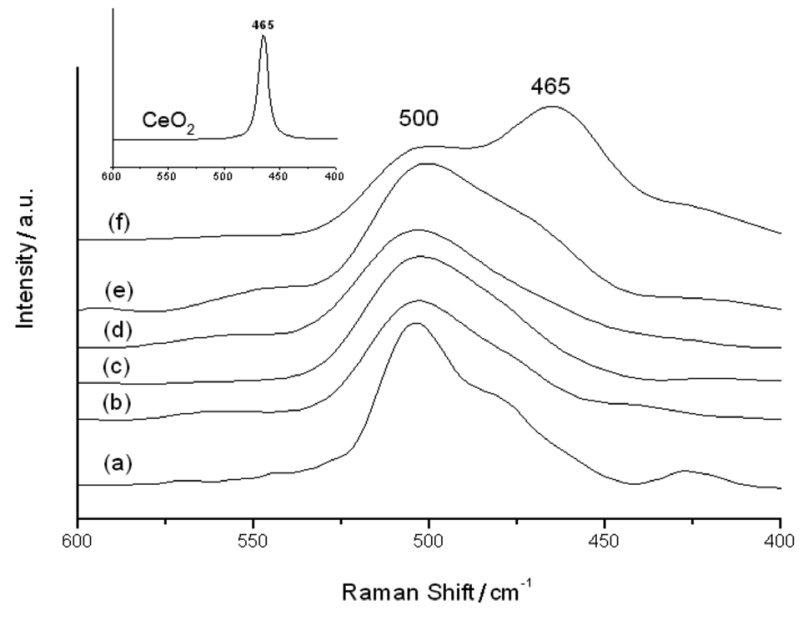

Figure 4. FT-Raman spectra of HUSY (a) and Ce-USY catalysts containing: 2 (b), 5 (c), 10 (d), 15 (e) and $25 \%$ wt. $\%$ of $\mathrm{CeO}_{2}$ (f) calcined at $550^{\circ} \mathrm{C}$ for $8 \mathrm{~h}$. The spectrum of $\mathrm{CeO}_{2}$ (inset) is also shown for comparison.

small crystallites of $\mathrm{CeO}_{2}$ did not show any peak in the diffractograms of the materials.

\section{Solid-state nuclear magnetic resonance spectroscopy}

The ${ }^{29} \mathrm{Si}$ MAS NMR spectra of HUSY and Ce-USY containing 2-25 wt.\% are shown in Figure S4. Ce-USY zeolites displayed five silicon environments (even after deconvolution) that were differentiated by the number of aluminum atoms on the second coordination sphere: $\mathrm{Si}(3 \mathrm{Al})$, $\mathrm{Si}(2 \mathrm{Al}), \mathrm{Si}(1 \mathrm{Al}), \mathrm{Si}(0 \mathrm{Al})$ and extra-framework silicon species. These sites appear at $-89.2,-96.6,-101.3,-106.4$ and -110 ppm respectively. ${ }^{20,32,42}$ The relative intensities of these signals after deconvolution are shown in Table S1. The signal related to the $\mathrm{Si}(4 \mathrm{Al})$ environment was not observed in the NMR spectra because the ultrastabilization process removed a considerable amount of framework aluminum, ${ }^{43}$ which eliminated the presence of this type of environment. In addition, the increasing contribution of extra-framework silicon species with cerium loading indicated that $\mathrm{SiO}_{4}$ tetrahedra were removed from the zeolitic structure. The observed increase of the $\mathrm{Q}^{4}$ silicon environment was related to the polymerization of monomeric extra-framework silicon species because the $\mathrm{Si}(\mathrm{OAl})$ environment of the samples was practically constant. Lutz et al. ${ }^{32}$ showed that acid treatment of a dealuminated zeolite led to the formation of polymeric $\mathrm{SiO}_{2}$ species within the structure of the zeolite, assigned at approximately $-110 \mathrm{ppm}$ in the NMR spectrum (silica gel $\mathrm{Q}^{4}$ environment). As already discussed, the procedure used to prepare Ce-USY zeolites was accompanied by the formation of $\mathrm{NH}_{4} \mathrm{Cl}$, which decomposed forming $\mathrm{HCl}$ that catalyzes silicon polymerization. Although the $\mathrm{SiO}_{2} \mathrm{Q}^{4}$ environment could be identified, the presence of other non-framework phases (e.g., silica gel $\mathrm{Q}^{2}$ and $\mathrm{Q}^{3}$ environments, monomeric
$\mathrm{SiO}_{2}$ ) cannot be completely excluded due to limitations of the spectral deconvolution method.

The ${ }^{27} \mathrm{Al}$ MAS NMR spectra of HUSY and Ce-USY zeolites containing 2-25 wt.\% presented two peaks at -0.4 and $59.1 \mathrm{ppm}$ related to octahedral, i.e., $\mathrm{Al}(\mathrm{VI})$, and tetrahedral, i.e., $\mathrm{Al}(\mathrm{IV})$ sites, respectively (Figure 5). In addition, a decrease in the intensity of the $\mathrm{Al}(\mathrm{VI})$ peak with increasing $\mathrm{CeO}_{2}$ loading was observed due to the loss of crystallinity, as determined by XRD results. Ghesti et al. ${ }^{22}$ reported a decrease in the intensity of EFAL and $\mathrm{Si}-\mathrm{O}(\mathrm{H})-\mathrm{Al}$ groups at 3642 and $3566 \mathrm{~cm}^{-1}$ using diffuse reflectance infrared Fourier transform spectroscopy (DRIFTS). There was also a convoluted signal between -0.4 and $59.1 \mathrm{ppm}$, which might be related to the presence of aluminum in distorted octahedral and/or tetrahedral sites. ${ }^{43,44}$

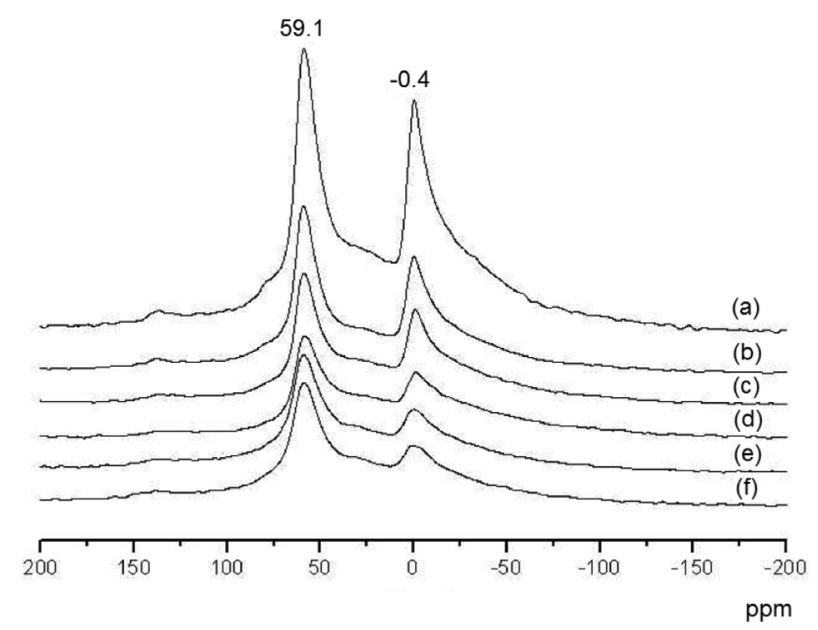

Figure 5. ${ }^{27} \mathrm{Al}$ MAS NMR spectra of HUSY (a) and Ce-USY catalysts calcined at $550{ }^{\circ} \mathrm{C}$ for $8 \mathrm{~h}$ containing 2 (b), 5 (c), 10 (d), 15 (e) and $25 \%$ wt. $\%$ of $\mathrm{CeO}_{2}$ (f).

The distribution of tetrahedral, octahedral and convoluted signals (intermediate aluminum sites) allowed a better comprehension of the dealumination process that the USY zeolite underwent upon calcination (Figure 6). The dealumination process involves the transformation of $\mathrm{Al}$ atoms from the structure to extra-framework atoms. Decreased tetrahedral sites and increased octahedral sites were observed with increasing cerium loadings up to $10 \mathrm{wt} . \%$. The samples with higher loadings (15 and 25 wt.\%) showed $\mathrm{HCl}$ concentrations that were capable of completely removing some of the $\mathrm{Al}(\mathrm{IV})$ sites from the zeolite framework, which decreased the intermediary species and increased the amount of octahedral sites. ${ }^{20}$

\section{Scanning electron microscopy}

SEM micrographs of HUSY and Ce-USY catalysts are shown in Figure 7. HUSY presented smooth spherical 


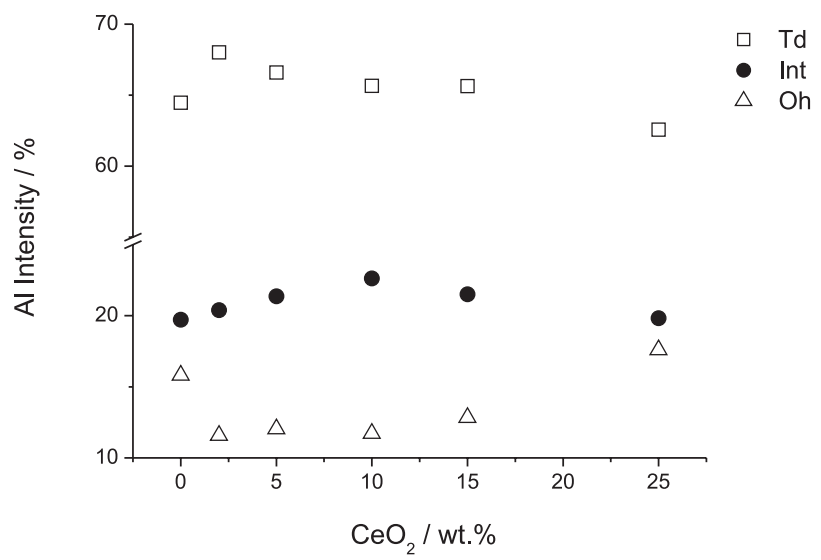

Figure 6. Plot of the distribution of tetrahedral (Td), octahedral (Oh) and intermediate (Int) aluminum sites of the Ce-USY catalysts (all calcined at $550{ }^{\circ} \mathrm{C}$ for $8 \mathrm{~h}$ ) as a function of cerium loading.

particles of $c a .500 \mathrm{~nm}$ of diameter with a homogeneous distribution throughout the solid. The catalysts with 2-10 wt.\% presented no perceptible morphological changes in comparison to HUSY, while those with 15 and $25 \mathrm{wt} . \%$ exhibited agglomerates that increased in number and in diameter up to $4 \mu \mathrm{m}$. This remarkable difference between the samples with low oxide loading and those with 15 and $25 \mathrm{wt} . \%$ is related to a much higher sinterization of cerium species in these samples. (a)

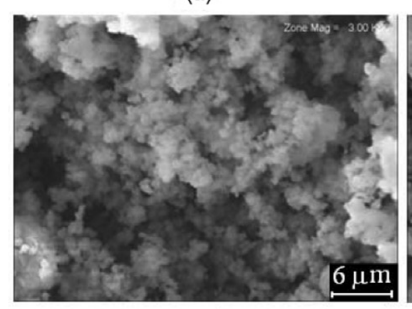

(c)

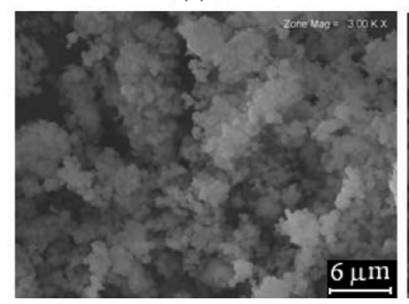

(e)
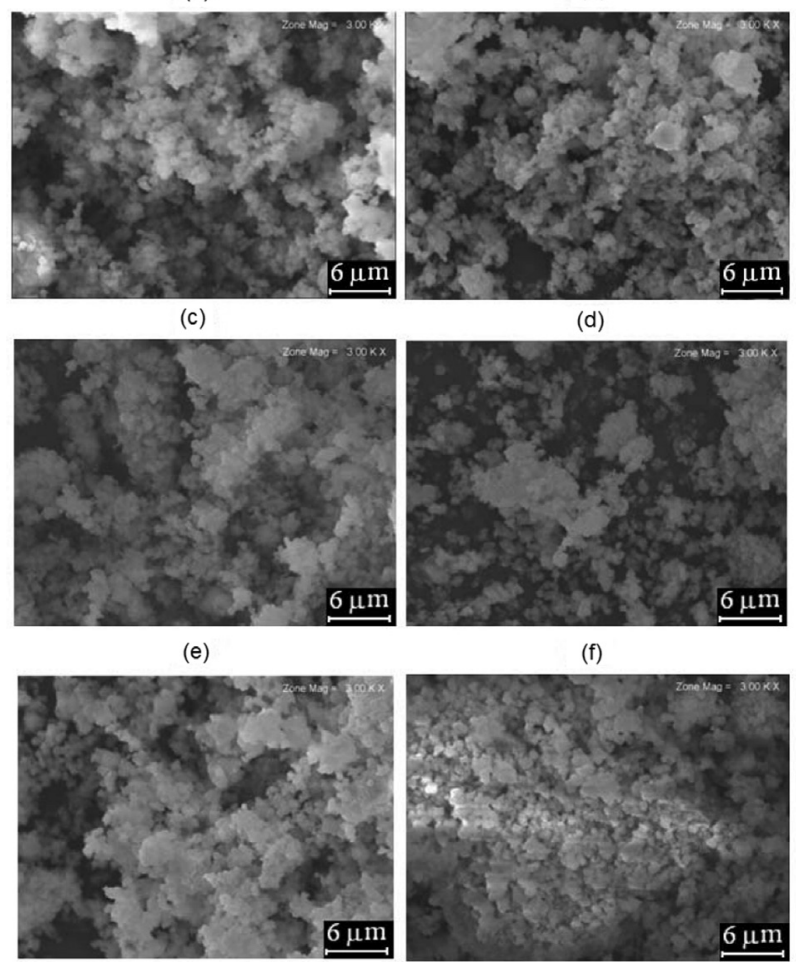

(d)

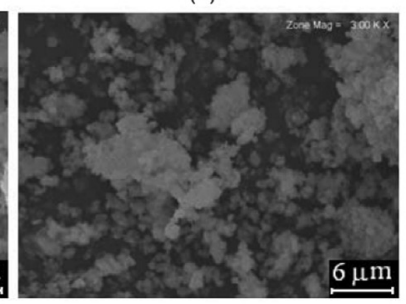

(f)

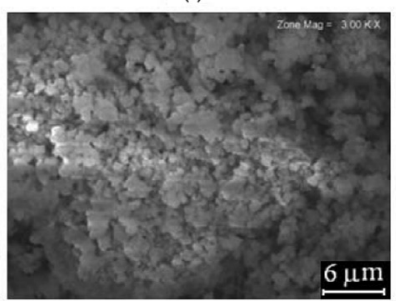

Figure 7. SEM micrographs of HUSY (a) and Ce-USY catalysts calcined at $550{ }^{\circ} \mathrm{C}$ for $8 \mathrm{~h}$ containing 2 (b), 5 (c), 10 (d), 15 (e) and $25 \%$ wt. $\%$ of $\mathrm{CeO}_{2}$ (f).

\section{Ce-USY acidity}

The Ce-USY acidity was investigated with gas phase adsorption of pyridine to correlate with the overall surface acidity of the samples. Pyridine was used to probe the acidity of Ce-USY samples by FTIR (Figure 8), which identified Brønsted and Lewis sites. ${ }^{44,45}$ The spectra showed three bands at 1545,1490 and $1445 \mathrm{~cm}^{-1}$, which are associated to Brønsted sites, a combination of Brønsted/ Lewis sites and Lewis sites respectively. ${ }^{46-48}$ The acidity of cerium materials has been widely discussed, but there is no consensus about the types of acid sites present on their surfaces..$^{49,50} \mathrm{Gu}$ et al. ${ }^{49}$ reported the presence of Brønsted and Lewis sites in $\mathrm{CeO}_{2}$ by ammonia adsorption studies. Ghesti et al. ${ }^{22}$ reported recently two types of acid sites with enthalpies of $-117.6 \mathrm{~kJ} \mathrm{~mol}^{-1}$ and $-83.6 \mathrm{~kJ} \mathrm{~mol}^{-1}$, which were assigned to Brønsted, and a combination of weak Brønsted/Lewis sites for 5 wt.\% Ce-HUSY. The impregnation of cerium reduced the acidity of the HUSY zeolite, which previously had Brønsted sites with enthalpies of $-134.0 \mathrm{~kJ} \mathrm{~mol}^{-1}$ and $-101.5 \mathrm{~kJ} \mathrm{~mol}^{-1}$, through the interaction with $\mathrm{Si}-\mathrm{O}(\mathrm{H})-\mathrm{Al}$ bridges, as observed by DRIFTS measurements. Although a definitive assignment of the hydroxyl bands in USY zeolites cannot be performed at this moment, the bands at 3566 and $3642 \mathrm{~cm}^{-1}$ were more affected by cerium than the other ones, indicating that the ion exchange between cerium ions and protons occurred during impregnation steps. ${ }^{22}$

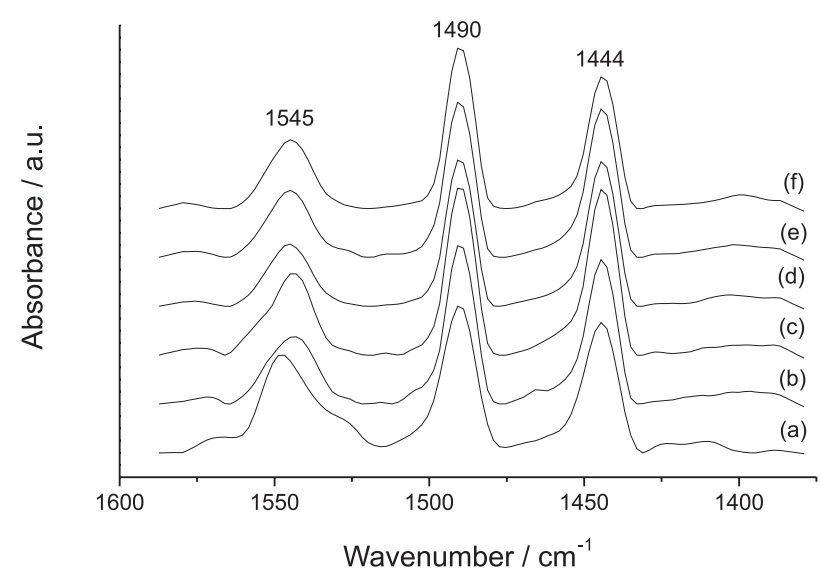

Figure 8. FTIR spectra of HUSY and Ce-USY (calcined at $550{ }^{\circ} \mathrm{C}$ for $8 \mathrm{~h}$ ) after pyridine adsorption and thermal desorption at $150{ }^{\circ} \mathrm{C}$ : HUSY (a) and Ce-USY catalysts containing 2 (b), 5 (c), 10 (d), 15 (e) and 25\% wt. $\%$ of $\mathrm{CeO}_{2}$ (f).

In the present study, an increase of the Lewis/Brønsted ratio with increasing cerium loadings was observed (Table 3), which was attributed to a decrease of Brønsted sites that interacted with cerium species and an increase of Lewis sites. For the samples with 15 and $25 \%$ loadings, a 
Table 3. Ratios between the Lewis and Brønsted sites obtained from the FTIR spectra after gaseous pyridine adsorption followed by thermal desorption at $150{ }^{\circ} \mathrm{C}$

\begin{tabular}{lc}
\hline Sample $^{\mathrm{a}}$ & $\left(\mathrm{L}_{\mathrm{py}} / \mathrm{B}_{\mathrm{py}}\right)^{\mathrm{b}}$ ratio \\
\hline 0 & 0.92 \\
2 & 1.44 \\
5 & 1.45 \\
10 & 1.69 \\
15 & 1.60 \\
25 & 1.37 \\
\hline
\end{tabular}

${ }^{a}$ Nominal $\mathrm{CeO}_{2}$ loading (wt. \%) on USY support (HUSY calcined at $550^{\circ} \mathrm{C}$ for $8 \mathrm{~h}$ ); ${ }^{b} \mathrm{~L}_{\mathrm{Py}}$ and $\mathrm{B}_{\mathrm{Py}}$ : pyridine interacting with Lewis and Brønsted sites, respectively.

decrease of the ratio could be an indication of the formation of cerium agglomerates with $25 \%$ loading, as observed with both SEM micrographs and FT-Raman spectroscopy.

\section{Conclusions}

The analysis of Ce-USY catalysts prepared with a wide loading range (2-25 wt.\% of $\mathrm{CeO}_{2}$ ) was performed with reliable techniques that provided valuable information regarding structural and morphological changes that USY underwent depending on cerium content.

Characterization of Ce-USY materials indicated that the samples with low cerium loadings (2-10\%) exhibited ion exchange degrees below the stoichiometric threshold, which led to the formation of $\mathrm{Ce}^{\mathrm{IV}}$ species linked to negatively charged $\mathrm{Al}$ in the framework. In addition, the samples with high loadings (15-25\%) exceeded this threshold, so that $\mathrm{CeO}_{\mathrm{x}}$ species were formed on the zeolite surface. The X-ray diffractograms of the Ce-USY catalysts exhibited only the reflections related to USY zeolite, demonstrating either interaction with USY or high dispersion of cerium species. Zeolite structural changes were also studied and are related to $\mathrm{HCl}$ formation by $\mathrm{NH}_{4} \mathrm{Cl}$ decomposition. The higher amount of $\mathrm{HCl}$ generated with higher cerium loadings led to an increase in the $\mathrm{Q}^{4}$ silicon environment, which is related to the polymerization of monomeric extra-framework silicon species. The high amount of $\mathrm{HCl}$ is also associated with a gradual extraction of the $\mathrm{Al}(\mathrm{IV})$ sites from the zeolite framework, forming distorted tetrahedra and/or octahedra for higher cerium concentrations (15-25\%).

The acidity of Ce-USY materials was also affected by cerium loading. The FTIR spectra showed the presence of both Brønsted and Lewis acidic sites. An increase in the Lewis/Brønsted ratio with increasing cerium loadings was observed and attributed to the interaction of zeolite $\mathrm{OH}$ surface groups with cerium species as well as an increase of Lewis sites with excess cerium. For the samples with 15 and $25 \%$ loading, the decrease of the ratio was consistent with the formation of $\mathrm{CeO}_{x}$ agglomerates, as observed in the SEM micrographs and detected by FT-Raman spectra.

\section{Supplementary Information}

Supplementary data (Figures S1-S4 and Table S1) are available free of charge at http://jbcs.org.br as a PDF file.

\section{Acknowledgments}

We thank the Conselho Nacional de Desenvolvimento Científico e Tecnológico (CNPq) for research, doctorate and undergraduate scholarships and acknowledge the financial support given by UnB/DPP/IQ, Coordenação de Aperfeiçoamento de Pessoal de Nível Superior (CAPES), Fundação de Empreendimentos Científicos e Tecnológicos (FINATEC), Financiadora de Estudos e Projetos (FINEP/ CTPetro, FINEP/CTInfra), Fundação de Apoio à Pesquisa do Distrito Federal (FAPDF) and Ministério da Ciência e Tecnologia (MCT/CNPq).

\section{References}

1. Xue, M.; Chitrakar, R.; Sakane, K.; Hirotsu, T.; Ooi, K.; Yoshimura, Y.; Toba, M.; Fengb, Q.; J. Colloid Interface Sci. 2006, 298, 535.

2. Puente, G.; Aguiar, E. F. S.; Zontin, F. M. Z.; Camorim, V. L. D.; Appl. Catal., A 2000, 197, 41.

3. Souza-Aguiar, E. F.; Camorin, V. L. D.; Zotin, F. M. Z.; Santos, R. L. C.; Microporous Mesoporous Mater. 1998, 25, 25.

4. Boxiong, S.; Chunfei, W.; Cai, L.; Binbin, G.; Rui, W.; J. Anal. Appl. Pyrolysis 2007, 78, 243.

5. Atoguchi, T.; Kanougi, T.; Yamamoto, T.; Yao, S.; J. Mol. Catal. A: Chem. 2004, 220, 183.

6. Neamtu, M.; Catrinescu, C.; Kettrup, A.; Appl. Catal., B 2004, $51,149$.

7. Zheng, J.; Guo, M.; Song, C.; Fuel Process. Technol. 2008, 89, 467.

8. Salinas, A. L. M.; Sapaly, G.; Taarit, Y. B.; Vedrine, J. C; Essayem, N.; Appl. Catal., A 2008, 336, 61.

9. Al-Khattaf, S.; Rabiu, S.; Tukur, N. M.; Alnaizy, R.; Chem. Eng. J. (Amsterdam, Neth.) 2008, 139, 622.

10. Sartori, G.; Maggi, R.; Chem. Rev. (Washington, DC, U. S.) 2006, 106, 1077.

11. Garcia, T.; Solsona, B.; Taylor, S. H.; Appl. Catal., B 2006, 66, 92.

12. Zhang, D.; Pan, C.; Shi, L.; Huang, L.; Fang, J.; Fu, H.; Microporous Mesoporous Mater. 2009, 117, 193. 
13. Beck, A.; Horváth, A.; Stefler, G.; Katona, R. O.; Geszti, G.; Tolnai, L. F.; Liotta, L.; Guczi, A.; Catal. Today 2008, 139, 180.

14. Petre, C. F.; Larachi, F.; Ind. Eng. Chem. Res. 2005, 44, 9391.

15. Gasser-Ramirez, J. L.; Dunn, B. C.; Ramirez, D. W.; Turpin, G. C.; Shi, Y.; Ernst, R. D.; Pugmire, R. J.; Eyring, E. M.; Pettigrew, K. A.; Rolison, D. R.; Harris, J. M.; J. Non-Cryst. Solids 2008, 354, 5509.

16. Yeung, C. M. Y.; Yu, K. M. K.; Fu, Q. J.; Thompsett, D.; Petch, M. I.; Tsang, S. C.; J. Am. Chem. Soc. 2005, 127, 18010.

17. Di Monte, R.; Fornasiero, P.; Graziani, M.; Kaspar, J.; J. Alloys Compd. 1998, 275, 877.

18. Reddy, J. K.; Suresh, G.; Hymavathi, C. H.; Kumari, V. D.; Subrahmanyam, M.; Catal. Today 2009, 141, 89.

19. Velu, S.; Ma, X.; Song, C.; Ind. Eng. Chem. Res. 2003, 42, 5293.

20. Giannetto, G.; Zeolitas: Características, Propriedades y Aplicaciones Industriales; Editorial Innovación Tecnológica: Caracas, Venezuela, 1990.

21. Lutz, W.; Rüscher, C. H.; Heidemann, D.; Microporous Mesoporous Mater. 2002, 55, 193.

22. Ghesti, G. F.; Macedo, J. L.; Parente, V. C. I.; Dias, J. A.; Dias, S. C. L.; Microporous Mesoporous Mater. 2007, 100, 27.

23. Galwey, A. K.; Brown, M. E.; Studies in Physical and Theoretical Chemistry, vol. 86; Elsevier: Amsterdam, 1999.

24. Figueiredo, J. L.; Ribeiro, F. R.; Catálise Heterogênea; Fundação Calouste Gulbenkian: Lisboa, Portugal, 1989.

25. Adamson, A. W.; Gast, A. P.; Physical Chemistry of Surfaces, $6^{\text {th }}$ ed.; John Wiley \& Sons: New York, 1997.

26. Yao, J.; Zhang, L.; Wang, H.; Mater. Lett. 2008, 62, 4028.

27. Schneider, P.; Hudec, P.; Solcova, O.; Microporous Mesoporous Mater. 2008, 115, 491.

28. Damyanova, S.; Perez, C. A.; Schmal, M.; Bueno, J. M. C.; Appl. Catal., A 2002, 234, 271.

29. Weckhuysen, B. M.; Schoonheydt, R. A.; Catal. Today 1999, $49,441$.

30. Garcia, F. A. C.; Silva, J. C. M.; Macedo, J. L.; Dias, J. A.; Dias, S. C. L.; Filho, G. N. R.; Microporous Mesoporous Mater. 2008, 113, 562 .

31. Rauscher, M.; Kesore, K.; Mönnig, R.; Schwieger, W.; Tibler, A.; Turek, T.; Appl. Catal., A 1999, 184, 249.
32. Lutz, W.; Toufar, H.; Heidemann, D.; Salman, N.; Rüscher, C. H.; Gesing, T. M.; Buhl, J.; Bertram, R.; Microporous Mesoporous Mater. 2007, 104, 171.

33. Nery, J. G.; Mascarenhas, Y. P.; Bonagamba, T. J.; Mello, N. C.; Sousa-Aguiar, E. F.; Zeolites 1998, 18, 44.

34. Lee, E. F. T.; Rees, L. V. C.; Zeolites 1987, 7, 446.

35. Lee, E. F. T.; Rees, L. V. C.; Zeolites 1987, 7, 143.

36. El-Bahy, Z. M.; Mater. Res. Bull. 2007, 42, 2170.

37. Moreira, C. R.; Schmal, M.; Pereira, M. M.; Stud. Surf. Sci. Catal. 2000, 143, 915.

38. Li, J.; Xiong, G.; Feng, Z.; Liu, Z.; Xin, Q.; Li, C.; Microporous Mesoporous Mater. 2000, 39, 275.

39. Smith, E.; Dent, G.; Modern Raman Spectroscopy: A Practical Approach; Wiley: New York, 2005.

40. Krishna, K.; Bueno-López, A.; Makkee, M.; Moulijn, J. A.; Appl. Catal., B 2007, 75, 189.

41. Al-Yassir, N.; Le Van Mao, R.; Appl. Catal., A 2007, 332, 273.

42. Gore, K. U.; Abraham, A.; Hedge, S. G.; Kumar, R.; Amoureux, J.; Ganapathy, S.; J. Phys. Chem. B 2002, 106, 6115.

43. Engelhardt, G.; Michel, D.; High-Resolution Solid-State NMR of Silicates and Zeolites; John Wiley \& Sons: New York, 1987.

44. Chronister, C. W.; Drago, R. S.; J. Am. Chem. Soc. 1993, 115, 4793.

45. Drago, R. S.; Dias, S. C.; Torrealba, M.; Lima, L.; J. Am. Chem. Soc. 1997, 119, 4444.

46. Kanellopoulos, J.; Unger, A.; Schwieger, W.; Freude, D.; J. Catal. 2006, 237, 416.

47. Garcia, F. A. C.; Braga, V. S.; Silva, J. C. M.; Dias, J. A.; Dias, S. C. L.; Davo, J. L. B.; Catal. Lett. 2007, 119, 101.

48. Zaki, M. I.; Hasan, M. A.; Al-Sagheer, F. A.; Pasupulety, L.; Colloids Surf., A 2001, 190, 261.

49. Gu, X.; Ge, J.; Zhang, H.; Auroux, A.; Shen, J.; Thermochim. Acta 2006, 451, 84.

50. Watanabe, M.; Osada, M.; Inomata, H.; Arai, K.; Kruse, A.; Appl. Catal., A 2003, 245, 333.

Submitted: February 21, 2011

Published online: July 26, 2011 


\title{
Effect of Cerium Loading on Structure and Morphology of Modified Ce-USY Zeolites
}

\author{
Fillipe A. C. Garcia, ${ }^{a}$ Daniel R. Araújo, ${ }^{a}$ Júnia C. M. Silva, ${ }^{a}$ Julio L. de Macedo, ${ }^{a}$

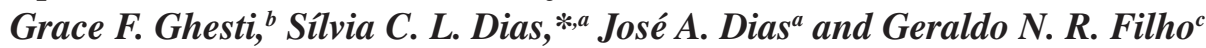 \\ ${ }^{a}$ Laboratório de Catálise, Instituto de Química and ${ }^{b}$ Engenharia de Energia, Faculdade UnB-Gama, \\ Universidade de Brasília, 70910-900 Brasília-DF, Brazil \\ ${ }^{c}$ Centro de Ciências Exatas e Naturais, Universidade Federal do Pará, Rua Augusto Correa no. 1, \\ 66075-010 Belém-PA, Brazil
}

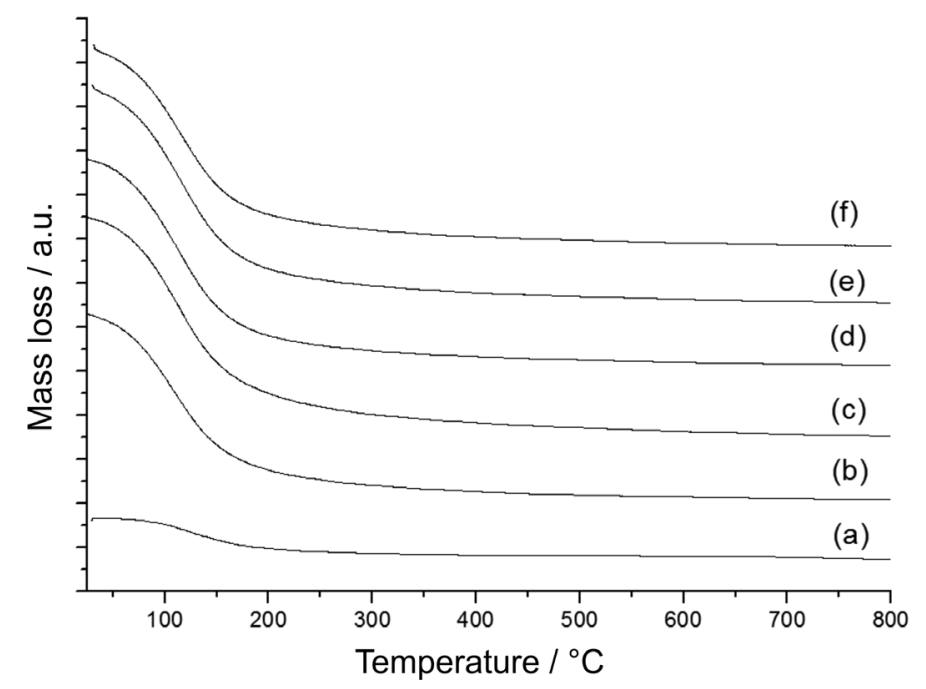

Figure S1. TGA curves of HUSY (a) and Ce-USY catalysts containing 2 (b), 5 (c), 10 (d), 15 (e) and 25 wt.\% of $\mathrm{CeO}_{2}$ (f), all after calcination. 

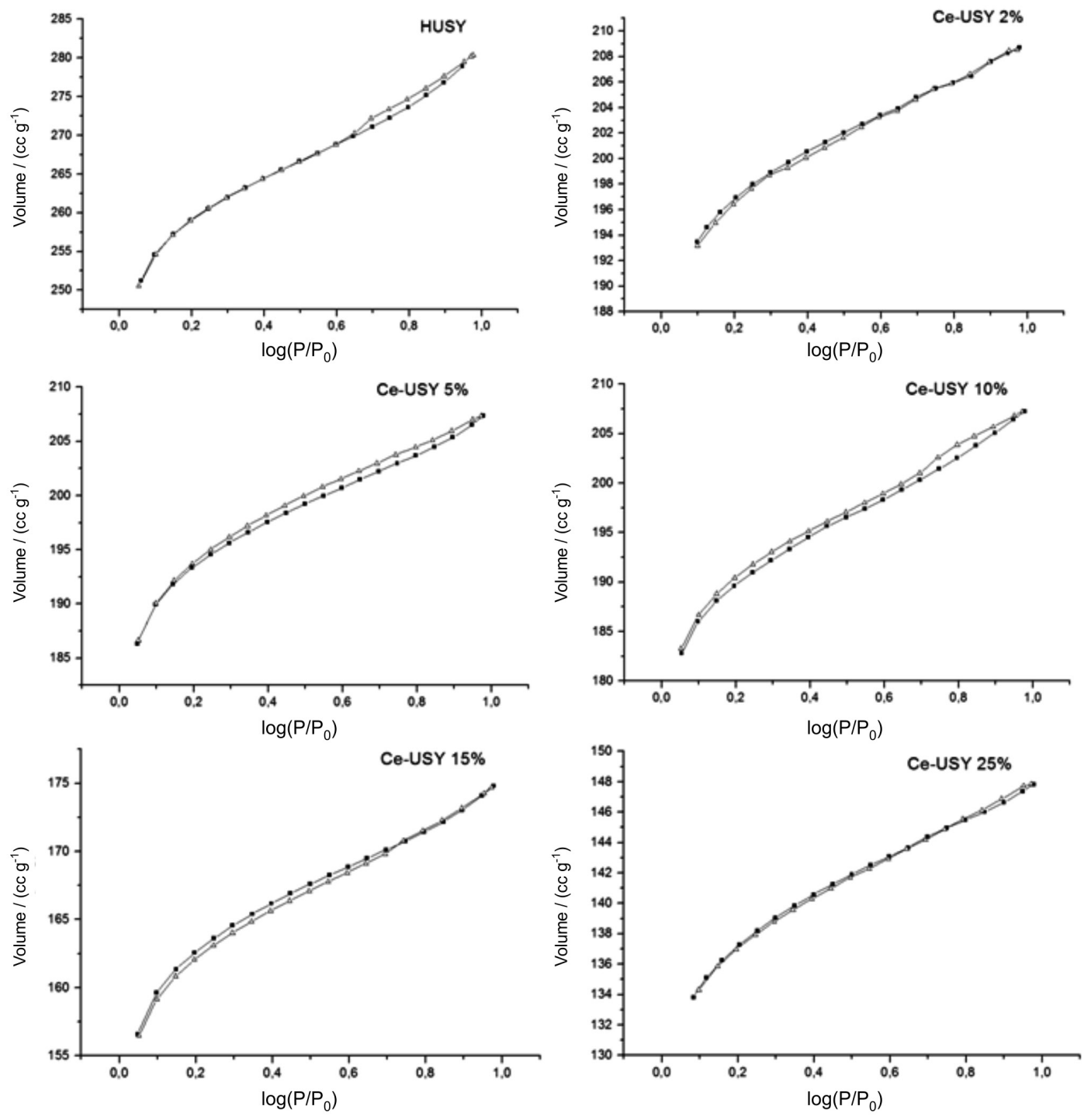

Figure S2. Adsorption and desorption nitrogen isotherms of HUSY (a) and Ce-USY catalysts containing 2 (b), 5 (c), 10 (d), 15 (e) and 25 wt. \% of CeO $($ f).

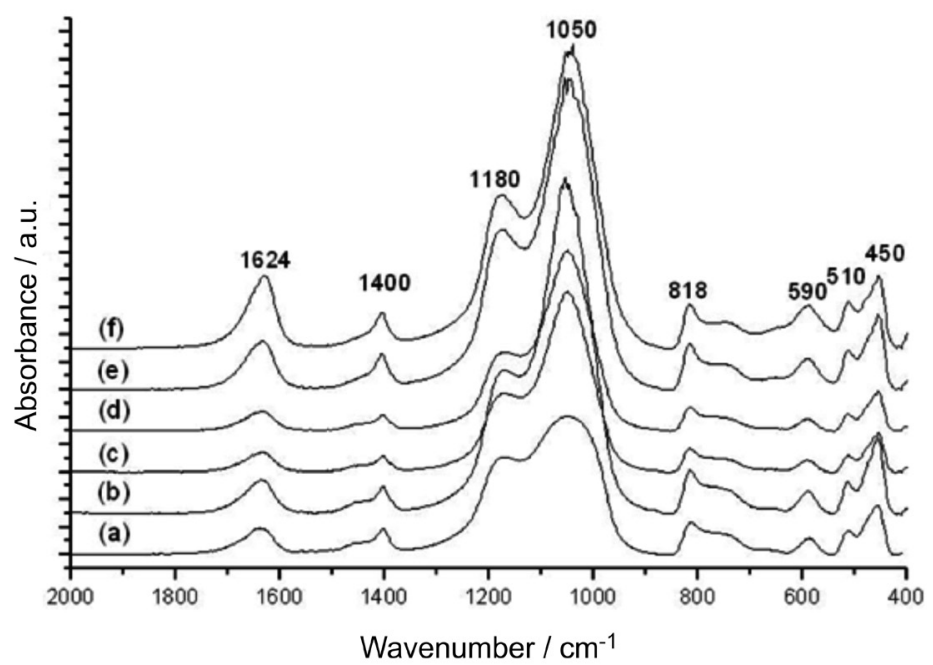

Figure S3. FTIR spectra of HUSY (a) and Ce-USY catalysts containing 2 (b), 5 (c), 10 (d), 15 (e) and $25 \%$ wt. $\%$ of $\mathrm{CeO}_{2}$ (f), all before calcination at $550^{\circ} \mathrm{C}$ for $8 \mathrm{~h}$. 

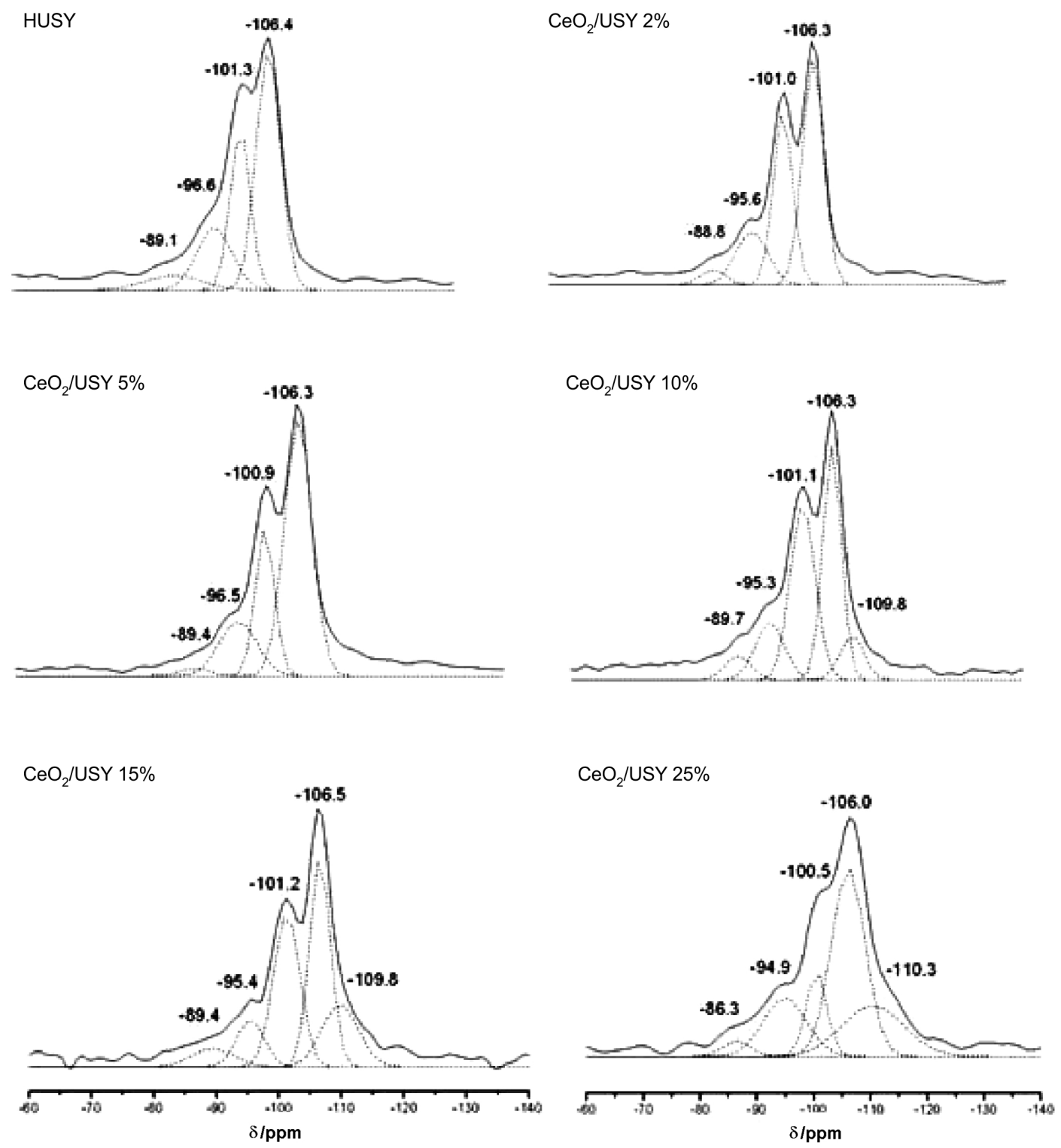

Figure S4. ${ }^{29} \mathrm{Si}$ MAS NMR spectra of HUSY (a) and Ce-USY catalysts calcined at $550{ }^{\circ} \mathrm{C}$ for $8 \mathrm{~h}$ containing 2 (b), 5 (c), 10 (d), 15 (e) and $25 \%$ wt. $\%$ of $\mathrm{CeO}_{2}$ (f).

Table S1. ${ }^{29} \mathrm{Si}$ MAS NMR deconvolution results for HUSY and Ce-USY $\left(2-25\right.$ wt. $\%$ of $\left.\mathrm{CeO}_{2}\right)$ calcined at $550{ }^{\circ} \mathrm{C}$ for $8 \mathrm{~h}$

\begin{tabular}{lccccc}
\hline Sample $^{\mathrm{a}}$ & $\mathrm{Si}(3 \mathrm{Al})$ & $\mathrm{Si}(2 \mathrm{Al})$ & $\mathrm{Si}(1 \mathrm{Al})$ & $\mathrm{Si}(0 \mathrm{Al})$ & $\mathrm{SiO}{ }_{2}^{\mathrm{b}}$ \\
\hline 0 & 0.023 & 0.129 & 0.335 & 0.476 & 0.036 \\
2 & 0.033 & 0.107 & 0.365 & 0.459 & 0.037 \\
5 & 0.019 & 0.097 & 0.337 & 0.487 & 0.060 \\
10 & 0.036 & 0.109 & 0.336 & 0.442 & 0.078 \\
15 & 0.025 & 0.092 & 0.323 & 0.437 & 0.123 \\
25 & 0.041 & 0.120 & 0.278 & 0.456 & 0.105 \\
\hline
\end{tabular}

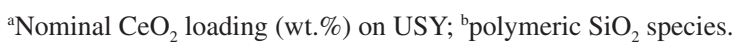

